Nataliya Antonyuk,

Ph.D., Sumy State University, Ukraine

ORCID ID, 0000-0001-8610-3219

email: n.antoniuk@finance.sumdu.edu.ua

Iryna Plikus,

Ph.D., Sumy State University, Ukraine

ORCID ID, 0000-0002-0657-7260

Mohammad Jammal,

Ph.D. in Educational Management and Leadership Policy,

The British University in Dubai, United Arab Emirates

(iD) ORCID ID, 0000-0002-0088-3523

Correspondence author: n.antoniuk@finance.sumdu.edu.ua

\title{
SUSTAINABLE BUSINESS DEVELOPMENT VISION UNDER THE COVID-19 PANDEMIC
}

Abstract. This article considers the issues of forming sustainable business development strategies in the context of the COVID-19 pandemic. The authors noted that the COVID-19 pandemic significantly affected the business environment, changing each country's economy's priorities and principles of functioning. The study's main goal is to analyze the impact of quarantine measures and the pandemic on sustainable business development. The article examines the positive and negative COVID-19 influence on economic development. The methodological basis of this study is a systematic literature review using international scientific databases. For determining the scientists' and the business interest in the studied issue, Google Trends and Google Ngram Viewer tools were used. The authors used a systematic approach, abstract-logical and structural-dynamic analysis to determine trends in entrepreneurial activity. This paper presents the findings in shifting prioritize business skills for future development. The obtained results showed that individual professional and personal development became more important compared to communication skills. The authors identified the negative pandemic consequences such as social stratification and significant psychoemotional pressure affecting socio-economic development. In turn, there is a need to quickly adapt to rapid changes, especially in the professional sphere was emphasized. The authors noted the inevitable digitalization process, which requires psychological readiness, stress resistance, cognitive flexibility, and emotional maturity. The obtained results allowed identifying the priorities of sustainable business development and areas of psychological support for private entrepreneurship in Ukraine. Thus, the formation of strategies for sustainable economic development in Ukraine should be based on business digitalization, adaptation to new business conditions, the acquisition of modern skills, reducing economic stratification of society, and reducing psychological stress. The study findings could be used in devising the regional development strategy to ensure a sustainable and efficient business environment. Moreover, the obtained results could be useful for the entrepreneurs to ensure personal development and get the desired level of profit while minimizing the business risks.

Keywords: sustainable development, business, COVID-19, digitalization, psychological stress, cognitive capacity, emotional intelligence.

Introducrion. The current COVID-19 restrictions require people to spend large time at home no matter for resting, studying, and working. Thus, the quarantine measures result in the growing number of active Internet users and data they produce. Notably, the coronavirus pandemic has shown that business processes could transform online without losing efficiency. Moreover, the COVID-19 restrictions aimed to minimize social activity significantly promoted IT solutions growth. Despite the overall negative impact on the global economy, the coronavirus pandemic was a trigger for the technological development in remote collaboration, large-scale processing, and big data analysis. In April 2020, the UN released a report calling

Cite as: Antonyuk, N., Plikus, I., \& Jammal, M. (2021). Sustainable Business Development Vision Under the Covid19 Pandemic. Health Economics and Management Review, 1, 37-43. http://doi.org/10.21272/hem.2021.1-04 37 
on countries to start «creating a new economy, as the old one would no longer be the same since the coronavirus pandemic COVID-19» (United Nations, 2020). At the same time, the World Economic Forum (WEF) established the "Stakeholder Principles in the COVID Era» (WEF, 2020b), clarifying and developing approaches to doing business responsibly. Reciprocally, the OECD launched the initiative to prevent spreading COVID-19 by emphasizing the support and development of relations between «key economic entities: employees, suppliers, consumers, the state, shareholders» (OECD, 2020) and other counterparties. Undoubtedly, digitalization leads to the emergence of new complex patterns of social development, while economic entities and society values transform.

It stands to note that on 26 January 2021, Accenture consulting company conducted a survey on 4051 executives in 13 countries and 19 industries (Tadviser, 2021). The findings showed that the COVID-19 crisis changed companies' priorities regarding sustainable development and slowed down companies' growth prospects. The statistical data analysis showed that $49 \%$ of European companies reported a decrease in income or profit over the previous 12 months and had no expectation to its improvement in the next 12 months; $19 \%$ of European companies with good financial performance before the pandemic expected revenue or profit declining in the next 12 months; 32\% of European companies expect profit growth in the next 12 months (Tadviser, 2021).

Besides, an investigation of companies, which are leaders in digital and sustainable practices, showed that they had approximately three times more likely to be among the «leaders of tomorrow» and businesses accelerating digitalization and sustainable development. Besides, they could recover faster after the economic crisis.

Following statistical data (State Statistic of Ukraine, 2021), 45\% of surveyed companies considered investing in digital transformation and sustainable development. In particular, $40 \%$ of respondents planned large investments in artificial intelligence, $37 \%$ - in cloud technologies, and $31 \%$ of respondents decided to invest in sustainable business models (Tadviser, 2021).

The current economic trends state the theoretical and practical significance of increasing the business efficiency and sustainability based on digital transformations. Besides, the WEF report 2019 on «The Universal Purpose of a Company in the Fourth Industrial Revolution» emphasized that business processes digitalization in sustainable business development leads to the business model transformation (WEF, 2019).

However, the systematization of scientific and practical sources has indicated the insufficient development of conceptual and methodological aspects of sustainable business development based on digital transformations. Therefore, this issue requires in-depth research.

Literature Review. In the studies (Karpenko et al., 2019; Plikus, 2019), authors indicated that it is necessary to consider the positive effects of digitalization and the growing risks, including labor, to create an innovative digital economy environment market risks. Besides, Plikus and Antoniuk (2020) considered the risks of workplace closure and labor market polarization from this perspective. Thus, digital inequality at the national and population levels leads to social stratification, extending to new industries, regions, and professional groups (Boronos et al., 2018). Following McKinsey \& Co estimations, the development of artificial intelligence and automatization would put $400-800$ million people out of work $(15-30 \%$ of the world's workforce) by 2030 (McKinsey \& Company, 2018). Thus, many current operations performed by employees could be automated. According to the study (Plikus and Antoniuk, 2020), modern technology could automate at least $30 \%$ of activities in approximately $60 \%$ of all professions. In turn, the European Commission (European Commission, 2020) stated that approximately 50\% of current jobs could theoretically be automated. The mentioned above means that particular processes by human labor would be out of demand. In the article (Usnews, 2018), Visual Capitalist analysis showed that by 2030 the US would digitize $50 \%$ of jobs in trade, $57 \%$ - the transport industry, $60 \%$ - agriculture, $60 \%$ - production, and more than $70 \%$ - accommodation and food. 
The World Economic Forum suggested that nearly $50 \%$ of workers would be forced to retrain by 2025 , while 85 million existing jobs may disappear by 2020. Besides, according to the report (WEF, 2020a), staff retraining and acquisition of new skills might take from 1 to 5 months, in turn: 1-2 months in sales, marketing, culture, and people-related fields; 2-3 months in the product development, data, and artificial intelligence development; 4-5 months - in engineering and cloud computing. The rapid spread of digital technologies prioritizes digital skills (competencies). Therefore, the professionals' ability to innovate and their digital competencies are essential in creating an innovative environment to provide businesses with new resources.

Based on the above, it is appropriate to note the research results (WEF, 2020a). Thus, its findings showed a $45 \%$ growth (65\% in 2018 vs. $94 \%$ in 2020) in the number of business leaders requiring their employees to acquire modern professional skills.

Methodology and research methods. This study aims to analyze the impact of quarantine measures and the pandemic on sustainable business development. The methodological basis of this study is a systematic literature review applying the publications from international scientific databases.

The study involved the online tools Google Trends and Google Ngram Viewer in tracing the dynamics of scientific and practical publications devoted to the investigated issues. It stands to mention that Google Trends allows tracking changes based on the most frequent search queries, while Google Ngram Viewer - the use of terms and concepts in book publications. In the study, the frequency of the keywords «digital economy», «knowledge economy», and «information society» was analyzed since they indicate a new socio-economic system that replaced the industrial paradigm (Fig. 1).

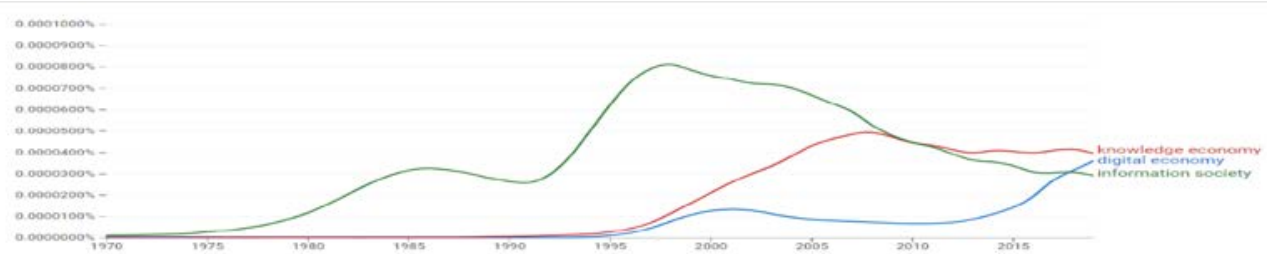

Figure 1. Frequency of keywords occurrence «digital economy», «knowledge economy», and «information society» in the English-language publications (1900-2019)

Sources: developed by the authors based on the (Google Ngram Viewer, 2020).

Figure 1 shows that public interest in the definitions of «digital economy», «knowledge economy», «information society» is distributed as follows:

- $\quad$ the maximum occurrence frequency of the «information society» was in 1998;

- $\quad$ the maximum occurrence frequency of the «knowledge economy» was in 2008;

- $\quad$ the maximum occurrence frequency of the «digital economy» was in 2018.

The analysis results of the last decades publications allow stating that creating innovative environment and innovations is indispensable for digital economy development by innovative business activity.

Results. Undoubtedly, the COVID-19 pandemic has significantly accelerated development in all areas, including the living environment. Rapid changes in living, studying, and working conditions, usually associated with decreased direct communication between people, provide psychological stress and pressure. Besides, there are changes in the self-identification of each individual in society.

The Report on the future of jobs 2020 (WEF, 2020a) confirms the above conclusion. This report presents the forecast for the Top 15 skills in 2025. Notably, this list included resilience and flexibility for the first time. In turn, the top skills were analytical thinking and innovation (first place) and active learning and problem-solving (second and third place, respectively). 
It is worth indicating that in the Top 10 skills 2025, «interpersonal communication» is represented only by leadership and social influence, «using of technology and inventions» by using technology and design technology, and design engineering. In turn, negotiating skills fell to the 15th position from Top 10 (WEF, 2020a). Meanwhile, professional and personal development skills became essential compared to communication skills. Based on the WEF data, two out of three employers expect a return on investment in human capital within one year (WEF, 2020a).

Therefore, it is believed that adaptation to the rapid changes caused by the COVID-19 pandemic would lead to inevitable digitalizing in almost all areas. Besides, it requires the psychological perception of new living conditions through developing stress resistance, cognitive functions flexibility, and emotional maturity.

Notably, the uncertainty of future welfare and lack of clear guidelines for personal development strategies provoke heavy psychological stress on the individual. Besides, they could significantly reduce a person's adaptive and cognitive abilities during a crisis. Thus, the employer and the state may partially assume duty in reducing these risks.

The WEF forecast indicates that two out of three employers expect a return on investment in human capital within one year (WEF, 2020a). Therefore, Ukrainian employers should adopt this tendency to invest in their employees to retrain them and acquire relevant skills and professional abilities.

According to the statistical data, for 2017-2020,60\% of Ukrainians had monthly income lower than the average level (State Statistic of Ukraine, 2021). Therefore, it is a barrier to invest in their self-development, including retraining and acquiring the necessary modern skills.

In the current Ukraine economic structure, private entrepreneurs need special support in adaptation to the crisis changes since they provide a large part of the budget revenues. Thus, in 2019, private entrepreneurs paid about 25 billion UAH (Foponomics, 2021).

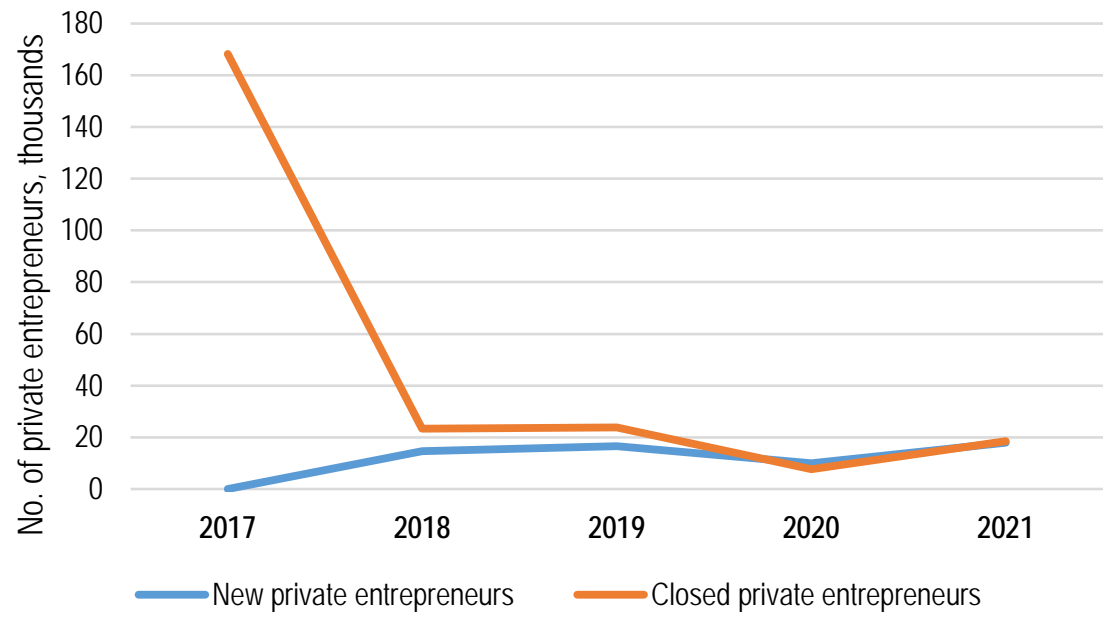

Figure 2. Dynamic of closed and new private entrepreneurs (2017-2021)

Sources: developed by the authors based on (Foponomics, 2021).

Figure 2 shows that the COVID-19 pandemic caused private entrepreneurs to withdraw from a market. Besides, the number of closed private entrepreneurs is near-equal to the new ones. It stands to mention that the entrepreneurial downturn above resulted from the long-term lockdown and the inability to reorient business activities under new conditions quickly. Thus, private entrepreneurs were affected by the 
coronavirus crisis at a quick pace. Besides, they felt the significant psychological burden arisen due to the risk of losing the main income sources.

Following mentioning above, state support has an enormous role in private entrepreneurial activity. In turn, the main steps to business support are as follows:

- digitalizing procedures regarding registration, re-registration, and closure of private entrepreneurs through the state online service «Diya. Business»;

- $\quad$ allocating state assistance amounting to 8 thousand UAH in case of closing business;

- deploying a digital literacy project in the online environment;

- $\quad$ providing publicly available templates for filling out documents on business registration, business plan development, financial and economic calculations on determining the effectiveness and payback of investment projects, etc.

As of 1 January 2021, the amount of operating private entrepreneurs was higher compared to 1 January in 2017 (Fig. 3). Thus, the data above points to quite effective state measures.

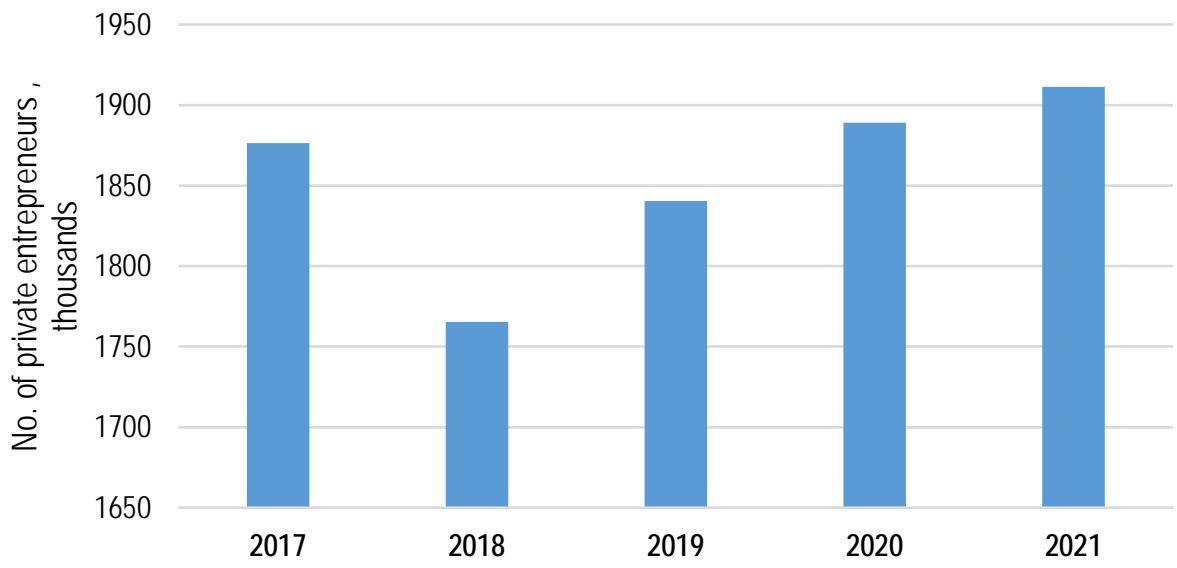

Figure 3. Dynamic of operating private entrepreneurs (2017-2021)

Sources: developed by the authors based on (Foponomics, 2021).

Despite the positive dynamics in private entrepreneurship growth, the COVID-19 pandemic and its consequences will intensify the changes in doing business. Therefore, along with the state support for entrepreneurs, it is necessary to create conditions for rapid business adaptation, in particular, to encourage flexibility, creativity, and innovation in doing business. In turn, it would reduce the psychological burden and social tension.

Notably, the first steps to provide psychological support to entrepreneurs and relieve psycho-emotional stress are provided by the online service «Diya. Business» (Diya. Business, 2021). With this, the Ukrainian business support concept during the coronavirus crisis and post-crisis period should be based on ensuring adaptive and cognitive abilities development. In turn, it would provide flexibility and creativity in making non-standard innovative business decisions. Both employers and the state can give psychological support to entrepreneurs through online counseling platforms to:

- reduce the psycho-emotional pressure caused by crisis changes;

- develop entrepreneurs' emotional intelligence to get a better understanding of themselves (their social and economic goals and priorities), and other people using this knowledge to achieve the expected socio-economic effect; 
- manage their own and others' emotional states;

- understand motivation and intentions and develop an adequate attitude to criticism of their business decisions and actions;

- promote creative and innovative thinking development;

- ensure self-identification in business, which represents the decision-making process of their status in the social and professional spheres, building a priorities system for future development, preparing and making optimal decisions in the context of problem situations;

- promote self-realization in business through logical development and realization of their potential in activities, communication, self-presentation in the online environment;

- form motivation system for self-realization in the social and economic spheres;

- prioritize the online skills (content-generating) against communication (for example, negotiation);

- ensure psychological perception and readiness to do online business through state resources.

Conclusions. This paper presents the sustainable business development priorities and directions of psychological entrepreneurship support in Ukraine. Undoubtedly, psychological support would allow avoiding social and economic efficiency risks in the long term. Besides, it could provide future steady business development rates in new market conditions caused by the COVID-19 pandemic.

The obtained results indicated the necessity to develop digital literacy among the population, promote digitalization in all areas, improve the financial state support for entrepreneurs, implement vaccination programs, and reduce social psycho-emotional burden.

Therefore, in developing sustainable economic strategies in Ukraine, it is essential to prioritize business digitalization, create favorable conditions for adapting to new business conditions, acquire skills adequate to modern socio-economic realities, reduce economic stratification and psychological stress caused by the COVID-19 pandemic.

The study findings could be used in devising the regional development strategy to ensure a sustainable and efficient business environment. Moreover, the obtained results could be useful for the entrepreneurs to ensure personal development and obtain the desired level of profit while minimizing the business risks.

Author Contributions: conceptualization, N. A. and I. P.; methodology, N. A.; software, I. P.; validation, N. A. and I. P.; formal analysis, N. A.; investigation, I. P.; resources, N. A.; data curation, I. P.; writing-original draft preparation, N. A.; writing-review and editing, I. P.; visualization, N. A.; supervision, I. P.; project administration, N. A.; funding acquisition, I. P.

\section{References}

Boronos, V., Plikus, I., Aleksandrov, V., Antoniuk, N. (2018). Digital transformation of Ukraine: challenges of theory and practice in implementation of digital quality of life. Economic Annals-XXI, 172 (№ 7-8. 38-43).

Diya.Business. (2021). No-cost consultation for future and operating entrepreneurs. Retrieved from [Link]

European Commission (2020). Threats and opportunities from automation and robotization. Retrieved from: [Link]

Foponomics (2021). The economy of Ukrainian private entrepreneurs in real time. Retrieved from [Link]

Karpenko, O., Plikus, I., \& Golovina, D. (2019). Digital economy: challenges for education and labor market in Ukraine (by the example of accounting and financial specialties). Pryazovskyi economic herald, 5(16), 221-228. [Google Scholar]

McKinsey \& Company (2018). Al, automation, and the future of work: Ten things to solve for. Executive Briefing. McKinsey Global Institute. Retrieved from [Link]

OECD. (2020). Tackling Coronavirus (COVID-19). Contributing to a Global Effort. COVID-19 and Responsible Business Conduct. Paris: OECD. Retrieved from [Link]

Plikus, I. Y., \& Antoniuk, N. A. (2020). The influence of digitalization on transformation processes on the labor market (Doctoral dissertation, Sumy State University). [Google Scholar]

Plikus, I. (2019). Entrepreneurship and independent employment in the digital economy: state, problems and new opportunities. Young Scientist, 11 (75), 591-595. [Link] 
State Statistics Service of Ukraine (2021). Expenditures and resources of Ukrainian households. Retrieved from [Link]

Tadviser (2021). Accenture: technologies and sustainable development will help businesses recover from the coronavirus crisis faster. Retrieved from [Link]

United Nations. (2020). A UN framework for the immediate socio-economic response to COVID-19. Retrieved from [Link]

Usnews. (2018). Top Industries To Be Changed by Automation. Retrieved from [Link]

WEF. (2019). Davos Manifesto 2020. The Universal Purpose of a Company in the Fourth Industrial Revolution. Geneva. Resource document. World Economic Forum 2019. Retrieved from [Link]

WEF. (2020a). The Future of Jobs Report 2020. Retrieved from [Link

WEF. (2020b). COVID Action Plan. Stakeholder principles in the COVID era. Geneva: World Economic Forum 2020. Retrieved from [Link].

Наталія Антонюк, к.е.н., Сумський державний університет (Україна);

Ірина Плікус, к.е.н., Сумський державний університет (Україна);

Мохаммад Джаммаль, PhD., Британський університет в Дубаї (Об'єднані Арабські Емірати)

Концепція сталого розвитку бізнесу в умовах пандемії COVID-19

Cтаття присвячена питанням формування стратегії сталого розвитку бізнесу в умовах пандемії COVID-19. Автори відмітили, що пандемія COVID-19 істотно вплинула на умови ведення бізнесу, змінивши пріоритети та принципи функиіонування економіки кожної країни. Метою дослідження є аналіз впливу карантинних заходів та пандемії, у иілому, на подальший розвиток бізнесу для забезпечення його сталого розвитку. Досліджено позитивні та негативні наслідки впливу COVID-19 на економічний розвиток. Методологічною основою дослідження $є$ системний огляд наукових напрацювань, представлених у міжнародних наукових базах даних. Для визначення інтересу науковців та бізнесспільноти до досліджуваного питання, було використано інструментарій онлайн-сервісів Google Trends ma Google Ngram Viewer. Авторами застосовано системний підхід, абстрактно-логічний та структурно-динамічний аналіз для визначення тенденцій підприємницької активності. У статті детально проаналізовано зміщення пріоритетів у формуванні необхідних навичок для реалізації ефрективної підприємницької діяльності у майбутньому. Отримані результати засвідчили, що профессійний та особистісний розвиток індивідуальності набуває більшого значення порівняно комунікативними навичками. Серед негативних наслідків пандемії було визначено розшарування суспільства та значне психоемоційне навантаження, що загрожує соціально-економічному розвитку. Автори наголосили на необхідності швидкої адаптації до стрімких змін, особливо у професійній сфрері. Так, неминучий процес диджиталізації вимагає психологічної готовності, стресостійкості, когнітивної гнучкості та емоційної зрілості. За результатами дослідження автори визначили пріоритети сталого розвитку бізнесу та напрями психологічної підтримки підприємницької діяльності в Україні. Таким чином, формування стратегій сталого економічного розвитку в Україні повинно базуватися на диджиталізації бізнес-процесів, адаптації до нових умов ведення бізнесу, набутті сучасних навичок, скороченні економічного розшарування суспільства та психологічної напруги. Результати дослідження можуть бути корисними при формуванні стратегії сталого регіонального розвитку, а також безпосередньо підприємиям для забезпечення особистого розвитку та отримання бажаного рівня прибутку з мінімізацією ризиків від своєї діяльності.

Ключові слова: сталий розвиток, бізнес, COVID-19, діджиталізація, психоемоційне навантаження, когнітивні здібності, емоційний інтелект. 